\title{
Evaluation of the validity of risk malignancy index in clinically diagnosed ovarian masses and to compare it with the validity of individual constituent parameter of risk malignancy index
}

\section{Kanan Avinash Yelikar*, Sonali Satish Deshpande, Sandip Sopan Nanaware, Sanjaykumar Bhaskarrao Pagare}

Department of Obstetrics \& Gynaecology, GMC, Aurangabad, Maharashtra, India

Received: 24 December 2015

Accepted: 23 January 2016

\section{*Correspondence: \\ Dr. Kanan Avinash Yelikar, \\ E-mail: drkanany@yahoo.co.in}

Copyright: () the author(s), publisher and licensee Medip Academy. This is an open-access article distributed under the terms of the Creative Commons Attribution Non-Commercial License, which permits unrestricted non-commercial use, distribution, and reproduction in any medium, provided the original work is properly cited.

\begin{abstract}
Background: Pre-operative knowledge regarding the nature of ovarian mass is necessary in order to plan surgery. Risk malignancy index (RMI) is a simple scoring system based on three factors serum CA 125 , USG score \& menopausal status. The RMI was interpreted as 1) score $>250=$ high risk, 2) $25-250=$ intermediate risk, 3 ) score $<25$ $=$ low risk. The objective of the study was, 1) to evaluate risk malignancy index (RMI) in pre-operatively clinically diagnosed ovarian mass, 2) to compare the validity of individual parameter in RMI i.e. menopausal status, serum CA 125 \& USG score with validity of RMI as a comprehensive index .

Methods: This was an observational study conducted at department of obstetrics and gynaecology, GMCH Aurangabad from October 2012 to 2014 with sample size of 102 cases with clinical diagnosis of ovarian mass admitted for laparotomy. The validity of RMI and validity of individual parameter was calculated and compared.

Results: RMI showed better sensitivity of $85.71 \%$, specificity of $85.07 \%$ and ppv of $75 \%$, npv of $91.93 \%$ and accuracy of $82.29 \%$ as compared to validity of individual parameters.

Conclusions: RMI is simple, valuable $\&$ highly reliable in pre-operative differentiation of malignant $\&$ benign lesion. Simplicity and applicability of this method in the primary evaluation of patients with pelvic masses makes it a good option in daily clinical gynaecological practice.
\end{abstract}

Keywords: USG, RMI, serum CA 125, Ovarian mass

\section{INTRODUCTION}

Ovarian cancer is one of the leading cause of mortality due to female genital tract malignancy. ${ }^{1}$ Ovarian cancer has emerged as one of the most common malignancy affecting Indian women. The annual percentage of increase in age standardized incidence rates ranged from $0.7 \%$ to $2.4 \%$. $^{2}$ Gynaecological cancers have increased in India and are estimated to be around 182,602 by the year 2020 constituting about $30 \%$ of the total cancers among women in India. Ovarian cancer contributes about $19.8 \%$ of the total cases. ${ }^{3}$
Risk malignancy index (RMI) is a simple scoring system based on three factors serum CA 125, USG score \& menopausal status. It is very useful in predicting a malignant ovarian mass. It is also useful in differentiating malignant from benign ovarian mass. In most of the cases ovarian tumours are diagnosed at a later stage since incidence of onset and progression of this tumour makes early diagnosis difficult.

Pre-operative knowledge regarding the nature of ovarian mass is necessary so as to plan surgery. There is a significant difference in management of a malignant tumour which may require radical surgery, chemotherapy, counselling regarding the disease 
prognosis and costs involved. On the other hand benign adnexal mass may simply be managed with cystectomy or laparotomy. This is adequate to signify the importance of pre-operative determination of the nature of adnexal mass for optimal and appropriate primary treatment.

Various combined methods of evaluating the risk of ovarian cancer have been proposed. ${ }^{4}$ The scoring methods based on menopausal status, ultrasonographic examination and serum CA-125 yield much better results than the earlier mentioned individual parameters. Risk of Malignancy Index (RMI) is calculated with a simplified regression equation obtained from the product of menopausal status score $(\mathrm{M})$, ultrasonographic score (U) and absolute value of serum CA-1255. RMI was originally developed by Jacobs et al at 1990. It is known as RMI-1 and that developed by Tingulstad et al with slight modification in score value of menopausal status and ultrasound score is RMI-2. ${ }^{5}$ It was modified to RMI-3 in $1999 .^{6}$

RMI is a simple scoring system which can be applied in less specialized centres. In many studies, cut off value of Risk of malignancy index was taken as 200 but according to $\mathrm{RCOG}$ guidelines, ${ }^{7}$ the cut off level is 250 for predicting malignancy since higher cut off level increased the detection rate of true negative cases.

Keeping this in mind, we have considered cut off level 250 for predicting malignancy in present study. ${ }^{7-9}$ This study was aimed to assess the validity of RMI in clinically diagnosed ovarian masses in pre-operative women \& comparing it with the validity of individual constituent parameter of RMI.

\section{METHODS}

This was an observational study conducted at department of obstetrics and gynaecology, GMCH Aurangabad from October 2012 to 2014 with sample size of 102 cases with clinical diagnosis of ovarian mass admitted for laparotomy.

\section{Inclusion criteria}

1. Women with clinically restricted ovarian mass of any age group.

2. For premenopausal women, criteria for ovarian masses are its size more than $8 \mathrm{~cm}$ and for postmenopausal women size more than $5 \mathrm{~cm}$.

3. Post-menopausal status defined as more than 1 year of amenorrhea or, women who underwent hysterectomy.

\section{Exclusion criteria}

1. Women having ovarian tumor with other condition like endometriosis, fibroid, pregnancy, PID, women in menstruating phase and associated with concurrent malignancy.
2. Patients who were unfit for major surgery, inoperable cases, previous major pelvic surgery.

3. Intra-operatively, any other mass than ovary was also excluded from study.

Total 102 women with clinically diagnosed as ovarian mass who were admitted for laparotomy in a tertiary care hospital, after fulfilling the inclusion and exclusion criteria were studied. Detailed clinical history was taken pertaining to their age, parity, socioeconomic status along with symptoms. Clinical examination was done. USG (abdomen + pelvis) performed with full bladder technique with 3-5 MHz probe frequency.

\section{Ultrasound scoring}

Ultrasound score (U) was based on one point for each of the following,

1. Bilateral lesion

2. Multilocular cyst or septation

3. Evidence of solid areas

4. Evidence of metastasis

5. Presence of ascites

\section{For RMI USG Score,}

$\mathrm{U}=0$ for ultrasound point of 0

$\mathrm{U}=1$ for ultrasound point of 1

$\mathrm{U}=3$ for ultrasound point of $2 \mathrm{OR}>2$

Ultrasound scoring were recent ones done within two weeks prior to laparotomy.

\section{Serum CA-125 level estimation}

Peripheral venous blood sample $(5 \mathrm{ml})$ was drawn from each patient, prior to surgery for the estimation of serum CA-125 level. Serum CA-125 level was determined by radioimmunoassay (MINIVEDAS CA-125 MACHINE). SERUM CA $125>200 \mathrm{IU} / \mathrm{ml}$ in premenopausal \& >35 $\mathrm{IU} / \mathrm{ml}$ in postmenopausal women were considered together as high risk of ovarian malignancy. ${ }^{10,11}$

\section{Menopausal Scoring (M)}

For premenopausal woman score 1 was given, for postmenopausal woman score 3 was given. RMI calculated for each subject by multiplying USG score, menopausal score and Serum CA125 level value.

$$
\mathrm{RMI}=\mathrm{U} \times \mathrm{M} \times \text { Serum CA-125 level }{ }^{12}
$$

Operative findings during laparotomy of all cases were obtained. It was made sure that the operated specimen or tissue was immersed in formalin solution and sent for histopathological examination; ascitic fluid or peritoneal washing was sent for cytological examination in a sterile syringe immediately. The cytological and histopathological examinations were all done in, 
department of Pathology. Histopathological diagnosis was considered as gold standard for defining outcome.

\section{Interpretation of risk malignancy index (RMI)}

If the score $<25$, it was considered as low risk,

If the score $25-250$, it was considered as, moderate risk \& If the score $>250$, it was considered as high risk.

Statistical analysis was done with appropriate test at the end of the study. ${ }^{7}$ Results of RMI were validated against histopathologically confirmed lesions.

\section{RESULTS}

Table 1 shows baseline characteristics of study group.

Table 1: Baseline characteristics.

\begin{tabular}{|ll|}
\hline Characteristics & Distribution \\
\hline Mean age & 34.6 years \\
\hline Mean parity & 2 \\
\hline Socioeconomic status & (Kuppuswami scale) \\
\hline Class I & $7.8 \%$ \\
\hline Class II & $9.8 \%$ \\
\hline Class III & $24.51 \%$ \\
\hline Class IV & $41.17 \%$ \\
\hline Class V & $6.66 \%$ \\
\hline
\end{tabular}

Table 2: Distribution of cases according to USG score, menopausal status, serum CA 125 levels and RMI.

\begin{tabular}{|lll|}
\hline Variable & $\begin{array}{l}\text { Total number } \\
\text { of ovarian } \\
\text { masses } \\
(\mathbf{n = 1 0 2})\end{array}$ & $\begin{array}{l}\text { \% Of } \\
\text { ovarian } \\
\text { masses } \\
\text { n=100 }\end{array}$ \\
\hline USG score & 6 & 5.8 \\
\hline 0 & 57 & 55.88 \\
\hline 1 & 39 & 38.2 \\
\hline 3 & 40 & \\
\hline Serum CA 125 in IU /ml & 39.22 \\
\hline CA-125> cut off & 62 & 60.78 \\
\hline CA-125< cut off & 40 & 39.22 \\
\hline Menopausal status & 62 & 60.88 \\
\hline Postmenopausal & & \\
\hline Premenopausal & 38 & 37.25 \\
\hline RMI & 24 & 23.52 \\
\hline$<25$ & 40 & 39.21 \\
\hline $25-250$ & & \\
\hline$>250$ & & \\
\hline
\end{tabular}

$38.2 \%$ women having USG score $>3,60.88 \%$ women were postm enopausal \& $39.22 \%$ cases having CA125 above cut off level, $39.21 \%$ cases having RMI $>250$.

Table 3: Co-relation of RMI and its individual parameter with histopathology.

\begin{tabular}{|c|c|c|c|c|}
\hline \multirow[b]{2}{*}{ Variables } & & \multicolumn{3}{|c|}{ Histopathology } \\
\hline & & $\begin{array}{l}\text { Malignant } \\
\mathrm{N}=35\end{array}$ & $\begin{array}{l}\text { Benign } \\
\mathrm{N}=67\end{array}$ & Total \\
\hline \multirow{2}{*}{ USG score } & USG score>3 & 28 & 11 & 39 \\
\hline & *USG score 0 or 1 & 7 & 56 & 63 \\
\hline \multirow{2}{*}{ CA-125 } & CA-125>cut off & 28 & 12 & 40 \\
\hline & CA-125<cut off & 7 & 55 & 62 \\
\hline \multirow{2}{*}{ Menopausal Status } & Postmenopausal & 21 & 19 & 40 \\
\hline & Premenopausal & 14 & 48 & 62 \\
\hline \multirow{2}{*}{ RMI } & $\mathrm{RMI}>250$ & 30 & 10 & 40 \\
\hline & $* * \mathrm{RMI}<250$ & 5 & 57 & 62 \\
\hline
\end{tabular}

*For statistical calculation purpose USG score 0 \& 1 combined together.

**For statistical analysis purpose, The RMI score (25-250)i.e. intermediate group was merge with group whose RMI was <25 i.e. Low risk group.

Table 4: Comparison of validity of RMI and validity of its individual parameter.

\begin{tabular}{|ccccccc|}
\hline Statistical parameter & Sensitivity & Specificity & PPV & NPV & \multicolumn{1}{c|}{ Accuracy } \\
\hline USG score & 80 & 83.88 & 71.79 & 88.88 & 82.58 \\
\hline Serum CA-125 Level & 80 & 82.08 & 70.00 & 88.78 & 81.08 \\
\hline Menopausal Status & 71.64 & 60.00 & 77.41 & 47.50 & 67.64 \\
\hline RMI & 85.71 & 85.07 & 75.00 & 91.93 & 82.29 \\
\hline
\end{tabular}


In cases RMI > 250, 30 were confirmed as malignancy. In cases USG score 0 or 1,56 were found to be benign. In cases serum CA125 above cut off level, 28 were found to be malignant. In postmenopausal women, 19 cases were found to be malignant

Sensitivity of menopausal status is $71.64 \%$ \& specificity of $60.00 \%$.

Sensitivity of Serum CA-125 was $80.00 \%$ \& specificity of $82.08 \%$.

Sensitivity of USG score was $80.00 \%$ \& specificity of $83.88 \%$.

Sensitivity of RMI is $85.71 \%$ \& specificity of $85.07 \%$.

\section{DISCUSSION}

Risk of malignancy index is the integration of serum CA125 , menopausal status and USG findings. In the present study, the cut off level of RMI is taken as 250.This scoring was more closer to Zinatossadat Bouzari et al, ${ }^{13}$ who used 265 as cut off .In the present study sensitivity, specificity, PPV \& NPV of RMI was found to be $85.71 \%, 85.07 \%, 75 \%$, 91.93\% respectively. Similar statistical significance was observed by Ismail Kestane et $\mathrm{al}^{14}$ and Zinatossadat Bouzari et al. ${ }^{13}$

In the present study, out of 102 clinically diagnosed ovarian masses, 7 cases were noted with lower RMI (i.e.<250 ) which turned out to be malignant on histopathology. This gave the false negative rate of $11.11 \%$. It was also noted that in these 7 cases, Serum CA 125 was within normal range. This could be explained on the basis of histopathology of individual cases. Out of these seven cases, three cases were of mucinous cystadenocarcinomas \& two were dysgerminomas, one was immature teratoma \& one case of sex cord stromal tumor (steroidal cell tumor). This could be because of serum CA-125 has limited role in recognizing mucinous cystadenocarcinomas. Similar findings were noted by Ismail Kestane et al. ${ }^{14}$ Immuno histochemical studies have demonstrated Serum CA-125 expression to be a feature of cells derived from embryonal coelomic epithelium and mullerian duct. ${ }^{15}$ Serum CA-125 levels usually rise in epithelial tumors whereas levels may not increase in non-epithelial tumor like dysgerminoma, immature teratoma , sex cord stromal tumor.

In the present study, USG score 0 was seen in $5.8 \%$ cases which resulted into RMI zero in those cases. Hence USG score 0 was major factor to contribute to more false negative results in RMI. This USG score 0 was excluded by Taherah Ashrafgangooei et al, ${ }^{16}$ M.A. Suuiqing et al, ${ }^{17}$ Ismail Kestane et $\mathrm{al}^{14}$ so as to decrease the false negative results. These authors included the USG score $1 \& 3$ only to calculate the RMI.

In the present study, menopausal status had a sensitivity of $60 \%$ \& specificity of $71.64 \%$. Hence menopausal status could be a weak constituent of RMI. Taherah
Ashrafgangooei et $\mathrm{al}^{16}$ had shown higher specificity of $93.18 \%$.This discrepancy in the present study was due to the proportion of sample size which included a larger number of pre-menapausal women as compared to postmenopausal $(86.3 \%)$.

Comprehensive index overcomes the false positive result obtained when using a single parameter like menopausal status or serum CA-125 or USG alone. RMI also increases the sensitivity \& specificity in the pre-operative diagnosis of ovarian mass.

If patients with ovarian cancers are diagnosed at early stage (I or II), the cure rate could be as high as $80-90 \%$ and the mortality rate could decrease up to $50 \%$. Hence, this method of diagnosis is of great importance for prediction of the prognosis. Selective referral of patients with high risk of malignancy to specialized oncology centers is of paramount importance. The primary cytoreductive surgery has a great role in deciding the prognosis of ovarian cancers.

\section{CONCLUSIONS}

RMI is simple, valuable, highly reliable \& clinically applicable scoring system, in pre-operative evaluation of ovarian mass. RMI is very useful in differentiating malignant from benign lesion.

The present study demonstrates that the validity of RMI is higher as compared to validity of individual parameters and hence, has a better discriminating power to diagnose malignancy.

Simplicity and applicability of the method in the primary evaluation of patients with pelvic masses, makes it a good option in daily clinical gynaecological practice.

Funding: No funding sources Conflict of interest: None declared

Ethical approval: The study was approved by the Institutional Ethics Committee

\section{REFERENCES}

1. Spencer JA. A multidisciplinary approach to ovarian cancer at diagnosis. The British J Radiol. 2005;78(2005):S95-102.rmi 17.

2. Murthy NS, Shalini S, Suman G, Pruthvish S, Mathew A. Changing trends in incidence of ovarian cancer - the Indian scenario. Asian Pac J Cancer Prev. 2009;10(6):1025-30.

3. Takiar R, Nadayil D, Nandakumar A. Projections of cancer cases in India (2010-2030) by cancer groups. Asian Pacific J Cancer Prev. 11:1045-104. rmi21.

4. Cruickshank DJ, Fullerton WT, Klcper A. The clinical significance of pre-operative serum CA-125 in ovarian cancer. Br J Obstet Gynecol. 1987;94:69295. 
5. Jacobs I, Oram D, Fairbanks J, Turner J, Crost C, Grudzinskas JG. A risk of malignancy index incorporating CA-125, ultrasound and menopausal status for the accurate pre-operative diagnosis of ovarian cancer. Br J Obstet Gynecol. 1990;97:92292.

6. Zalel Y, Tepper R, Altaras M, Beyth Y. Transvaginal sonographic measurements of postmenopausal ovarian volumes as a possible detection of ovarian neoplasia. Acta Obstet Gynecol Scand. 1996;75:66871.

7. RCOG Guideline No. 34 October 2003, Reviewed 2010.

8. Hartge P, Hayes R, Reding D, Sherman ME, Prorok $\mathrm{P}$, Schiffman $\mathrm{M}$ et al. Complex ovarian cysts in postmenopausal women are not associated with ovarian cancer risk factors: preliminary data from the prostate, lung, colon, and ovarian cancer screening trial. Am J Obstet Gynecol. 2000;183:1232-7.

9. Barber HR, Graber EA. The PMPO syndrome (postmenopausal palpable ovary syndrome). Obstet Gynecol. 1971;38:921-3.

10. Lippincott Williams \& Wilkins. The American College of Obstetricians and Gynecologists (ACOG). 2015;105(1).

11. ACOG Committee Opinion: number 280, December 2002. The role of the generalist obstetriciangynecologist in the early detection of ovarian cancer. Obstet Gynecol. 2002;100:1413-6.

12. Tingulstad S, Hagen B, Skjeldestad FE, Onsrud M, Kiserud T, Halvorsen et al. Evaluation of risk of malignancy index based upon serum CA-125, ultrasound score and menopausal status in the preoperative diagnosis of pelvis masses. $\mathrm{Br} \mathrm{J}$ Obstet Gynaecol. 1996;103:826-31.

13. Bouzari Z, Yazdani S, Ahmadi MH, Barat S, Kelagar ZS, Kutenaie MJ et al. Comparison of three malignancy risk indices and CA-125 in the preoperative evaluation of patients with pelvic masses. BMC Res Notes. 2011;4:206.

14. Kestane I, Senol T, Kahramanoglu I, Kestane D. The use of risk of malignancy index for adnexal masses. Gynecol Obstet. 2014;4:226.

15. Kabawat SE, Bast RC, Welch WR, Knapp RC, Calvin RB. Immunopathologic characterization of a monoclonal antibody that recognizes common surface antigens of human ovarian tumours of serous, endometrioid and dear cell types. Am J Clin Pathol. 1983;79:98-104.

16. Tahereh A, Mahdieh R. Risk of malignancy index in preoperative evaluation of pelvic masses. Asian Pac J Cancer Prev. 2011;12:1727-30.

17. Shuiqing Ma, Keng S, Jinglie LA. Risk of malignancy index in pre-operative diagnosis of ovarian cancer. Chin Med J. 2003;116(3):396-9.

Cite this article as: Yelikar KA, Deshpande SS, Nanaware SS, Pagare SB. Evaluation of the validity of risk malignancy index in clinically diagnosed ovarian masses and to compare it with the validity of individual constituent parameter of risk malignancy index. Int J Reprod Contracept Obstet Gynecol 2016;5:460-4. 